\title{
IbM PEMBENTUKAN POS EDUKASI AVIAN INFLUENZA UNTUK MENCIPTAKAN SISWA YANG TANGGAP AVIAN INFLUENZA DI PROVINSI BENGKULU
}

\section{SCHOOL BASED EDUCATIVE SHELTER ESTABLISHMENT TO CREATE PERCEPTIVE STUDENTS ON ISSUE OF AVIAN INFLUENZA IN BENGKULU}

\author{
Oleh: \\ Heri Dwi Putranto ${ }^{1)}$, Hardi Prakoso ${ }^{1)}$, Nurmeliasari ${ }^{1)}$, Apri Andani ${ }^{2)}$, dan Yossie Yumiati ${ }^{3)}$ \\ ${ }^{1)}$ Jurusan Peternakan Fakultas Pertanian Universitas Bengkulu \\ ${ }^{2)}$ Jurusan Sosial Ekonomi Pertanian Fakultas Pertanian Universitas Bengkulu \\ ${ }^{3)}$ Prodi Agribisnis Fakultas Pertanian Universitas Dehasen Bengkulu \\ Email: heri_dp@unib.ac.id
}

\begin{abstract}
Avian influenza (AI) has become a problem for livestock industry mainly for Indonesia poultry industry. It will cost for some economic values and activities, furthermore, it will also disturb the people's daily lives for the probability of H5N1 virus transmission (from animal to human) which can be lead to deadly case in poultry and humans infected. By a collaboration with Dinas Kelautan, Peternakan dan Perikanan (DKPP), researchers have visited some schools including SMA Negeri 3 Pondok Kelapa, SMP N 2 Giri Mulya and SD Negeri 7 Kerkap. The purpose of this study was to establish school based educative shelter in order to improve student's knowledge on AI issue. By a series of activities, extension on AI biosecurity activities followed by a practical demo on AI biosecurity and educative shelter establishment. Three (3) shelters were established in SMA Negeri 3 in District of Pondok Kelapa, SMP Negeri 2 in District of Giri Mulya and SD Negeri 7 in District of Kerkap.
\end{abstract}

Keywords: Avian Influenza, Educative Shelter, IbM, Students Perceptive

\section{PENDAHULUAN}

Berdasarkan buku Petunjuk Bagi Paramedik Veteriner yang dipublikasikan oleh Food and Agriculture Organization (FAO, 2014:3) disebutkan bahwa flu burung atau avian influenza (AI) merupakan penyakit yang disebabkan oleh virus dan menyerang beberapa unggas sebagai induk semang alaminya seperti ayam, itik, angsa, kalkun dan burung liar lainnya. Menurut Radji (2006:55), virus AI H5N1 digolongkan ke dalam higly pathogenic avian influenza (HPAI) yang dapat saja berkembang menjadi pandemi di seluruh dunia. Selanjutnya disebutkan bahwa AI merupakan penyakit yang berbahaya karena dapat membunuh seluruh ternak unggas di areal usaha peternakan dan berbahaya karena banyak jenis AI dapat menyebabkan manusia sakit dan meninggal. 
Di Provinsi Bengkulu, kasus AI pada peternakan rakyat di beberapa desa di Kecamatan Pondok Kelapa terjadi di tahun 2011, 2012 dan terakhir di bulan April tahun 2013 (komunikasi pribadi dengan Drh. Iyan Kurniawan dari Pusat Kesehatan Hewan Kabupaten Bengkulu Tengah). Desa - desa tersebut adalah Desa Talang Pauh, Desa Sri Kuncoro, Desa Panca Mukti dan Desa Pekik Nyaring. Perlu diketahui bahwa sekolahsekolah yang menjadi mitra kegiatan ada yang berdiri di lokasi yang sama dengan desadesa yang disebutkan di atas, atau letaknya berdekatan dengan desa-desa tersebut. Bahkan di tahun 2012, kasus AI juga terjadi pada beberapa tempat di kecamatan Sukaraja dan Kota Bengkulu.

Desa-desa yang disebutkan di atas adalah desa yang bersebelahan dengan desa Sri Katon yaitu desa binaan Jurusan Peternakan, Fakultas Pertanian, Universitas Bengkulu bekerjasama dengan Bank Indonesia dengan kegiatan utama fokus pada komoditas ternak ayam petelur. Beberapa desa seperti Desa Talang Pauh, merupakan lokasi pemeliharaan unggas dalam skala relatif besar yang bermitra dengan perusahaan dari luar Bengkulu. Meskipun tidak dilaporkan korban manusia yang terinfeksi AI di Kabupaten Bengkulu Tengah, adanya beberapa kasus infeksi AI pada unggas telah menimbulkan kerugian yang sangat besar bagi perekonomian peternak dan pedagang. Hal ini juga berdampak negatif terhadap status gizi masyarakat karena penduduk takut untuk mengkonsumsi unggas dan semua produk unggas.

Ketakutan masyarakat ini dikarenakan keterbatasan informasi mengenai AI yang sampai kepada mereka. Dari survei di lapangan diketahui bahwa masyarakat masih sangat minim pengetahuannya akan AI (Nurmeliasari et al., 2014:7). Sebagian besar masyarakat tidak mengetahui tanda-tanda infeksi AI pada ayam, belum memahami cara penyebaran AI, cara mencegah penyebaran AI, cara melindungi diri dari AI dan cara mengolah produk unggas agar higienis dan terhindar dari potensi infeksi AI. Sebagai contoh, saat masyarakat menduga ternak unggas peliharaan mereka yang mati mendadak karena AI, maka mereka berbondong-bondong mendatangi puskesmas untuk meminta Tami Flu.

Obat Tami Flu mereka konsumsi karena takut terinfeksi padahal obat ini hanya diberikan sebagai upaya penanganan awal bagi penderita AI pada manusia. Hal negatif lainnya adalah sistem pemeliharaan ternak unggas yang dipraktikkan mayoritas masyarakat di kecamatan ini adalah sistem tradisional dengan sanitasi yang buruk dengan rata-rata kepemilikan sepuluh ekor per kepala keluarga. Masyarakat pada daerah yang terinfeksi ini perlu informasi lengkap mengenai AI dan praktik penyemprotan desinfektan perlu dilakukan untuk meningkatkan biosekuriti karena menurut Putranto et al., (2012:2) beternak ayam bagi peternak di Bengkulu adalah budaya masyarakat dengan tujuan sebagai tabungan, ternak kesayangan/ternak hias, sumber protein hewani keluarga dan untuk sumbangan kegiatan sosial desa seperti pesta pernikahan.

Program ini sejalan dengan program Komnas Pengendalian Flu Burung dan Pandemi Influenza 2009 yang mentargetkan terwujudnya kampanye informasi dan pendidikan mengenai AI berbasis sekolah. Kegiatan yang berlokasi di Kecamatan Pondok Kelapa, Kecamatan Giri Mulya dan Kecamatan Kerkap ini bertujuan untuk mewujudkan 
kesiapsiagaan siswa menghadapi pandemi AI secara komprehensif dan terpadu sehingga dapat mencegah bertambahnya korban jiwa dan kerugian finansial pada masyarakat yang lebih besar.

\section{METODE PENGABDIAN}

Melalui kegiatan Pengabdian Pada Masyarakat (PPM) program Ipteks bagi Masyarakat (IbM) tahun 2014, tim pelaksana melakukan beberapa upaya untuk mengatasi permasalahan keterbatasan pengetahuan siswa sekolah dan masyarakat tentang biosekuriti AI di Provinsi Bengkulu dengan beberapa tahapan kegiatan. Adapun tahapan-tahapan kegiatan tersebut dapat dilihat dalam Tabel 1.

Tabel 1. Tahapan Kegiatan PPM Program IbM tahun 2014

\begin{tabular}{|c|c|c|c|}
\hline Tahap & Jenis Kegiatan & Lokasi & Target Sasaran \\
\hline 1 & Persiapan & Kampus UNIB & $\begin{array}{c}\text { Tim Pelaksana dan } \\
\text { Mahasiswa Pendamping }\end{array}$ \\
\hline 2 & Pembekalan & Kampus UNIB & Mahasiswa Pendamping \\
\hline 3 & Sosialisasi Kegiatan & $\begin{array}{l}\text { Mitra PPM IbM } \\
\text { (Kantor DKPP, } \\
\text { Sekolah-sekolah) }\end{array}$ & $\begin{array}{l}\text { Pimpinan, staf, dewan } \\
\text { guru mitra PPM IbM }\end{array}$ \\
\hline 4 & Penyuluhan Biosekuriti AI & Sekolah Mitra & $\begin{array}{l}\text { SMA N } 3 \text { dan SMP N } 1 \\
\text { Kec. Pondok Kelapa, } \\
\text { SMP N } 2 \text { Kec. Giri } \\
\text { Mulya dan SD N } 7 \text { Kec. } \\
\text { Kerkap }\end{array}$ \\
\hline 5 & $\begin{array}{l}\text { Demplot Penyemprotan } \\
\text { Biosekuriti AI }\end{array}$ & Sekolah Mitra & SMP N 2 dan SD N 7 \\
\hline 6 & Pembentukan Pos Edukasi AI & Sekolah Mitra & $\begin{array}{c}\text { SMA N } 3, \text { SMP N } 2 \text { dan } \\
\text { SD N } 7\end{array}$ \\
\hline 7 & Monitoring dan Evaluasi & Kampus UNIB & $\begin{array}{l}\text { Tim Pelaksana dan } \\
\text { Mahasiswa Pendamping }\end{array}$ \\
\hline
\end{tabular}

Pada Tahap 1, tim pelaksana merekrutkan sebanyak 4 orang mahasiswa Prodi Peternakan Jurusan Peternakan Universitas Bengkulu dan 3 orang mahasiswa peserta KKN periode 73 yang bertugas sebagai Mahasiswa Pendamping dalam kegiatan PPM IbM tahun 2014 ini. Mahasiswa yang terlibat selanjutnya mendapatkan pelatihan tentang biosekuriti AI dan penjelasan tentang tahapan kegiatan yang akan dilakukan.

Selanjutnya, para mitra kegiatan yang setuju untuk terlibat dalam kegiatan PPM IbM tahun 2014 ini (staf dari Dinas kelautan, Peternakan dan Perikanan serta dewan guru sekolah mitra) disosialisasikan tentang maksud dan tujuan PPM IbM tahun 2014. Sosialisasi juga termasuk tentang materi utama Biosekuriti AI serta tahapan kegiatan 
sekaligus perizinan kegiatan dari pihak otoritas terkait. Setelah tahap sosialisasi dianggap cukup, tim pelaksana selanjutnya melaksanakan kegiatan penyuluhan, praktik demplot penyemprotan dan pembentukan Pos Edukasi AI di sekolah mitra kegiatan.

Tim pelaksana melengkapi diri dengan presentasi power point tentang biosekuriti AI, poster tentang biosekuriti AI, pamflet tentang biosekuriti AI, film dokumenter ilmiah tentang "Biosekuriti untuk Unggas" yang bersumber dari USDA dan California Department of Food and Agriculture dalam versi Bahasa Indonesia, poster papan nama Pos Edukasi AI, alat-alat penyemprot, obat/desinfektan penyemprotan biosekuriti AI, sarung tangan, masker dan sepatu karet untuk demplot praktik.

\section{HASIL DAN PEMBAHASAN}

Dewasa ini, AI bukan hanya menyerang unggas dan manusia saja. Menurut Natsir (2010:2), AI dapat menginfeksi semua jenis unggas, manusia, babi, kuda dan anjing. Virus ini merupakan virus AI tipe A dari family Orthomyxoviridae. Ditambahkan oleh Darminto (2006:3), AI bersifat zoonosis dan virus penyebabnya memiliki tingkat mutasi yang tinggi, sehingga penyakit ini memiliki dampak sosial, ekonomi dan politik yang cukup besar.

Tim pelaksana PPM IbM tahun 2014 telah menjalin kemitraan dengan DKPP dan beberapa sekolah mulai dari tingkat pendidikan dasar, pendidikan menengah tigkat pertama hingga sekolah menengah tingkat atas yang ada di Provinsi Bengkulu. Mengingat pentingnya pengenalan tentang penyakit AI, gejala dan mekanisme pecegahan serta pemusnahannya maka materi tentang biosekuriti AI menjadi materi utama pada saat penyuluhan.

Materi yang telah dipersiapkan oleh tim pelaksana dibuat dalam bentuk presentasi power point dan leaflet yang kemudian dibagikan kepada setiap siswa, guru dan staf sekolah lokasi kegiatan. Adapun materi biosekuriti AI tersebut antara lain:

a. Pengenalan Penyakit AI

Siswa peserta penyuluhan diberikan informasi tentang 2 tipe penyakit AI yaitu tipe higly pathogenic avian influenza (HPAI) dan low pathogenic avian influenza (LPAI).

b. Cara Penularan Penyakit AI

Penyakit AI dapat menular dari beberapa vektor antara lain dari ternak unggas dan babi ke manusia atau manusia ke manusia. Cara penularan dapat melalui kontak langsung ataupun kontak tidak langsung. Kontak langsung terjadi apabila ternak atau manusia sehat bersentuhan langsung (memegang, menyentuh atau memakan produk) dengan ternak yang terserang penyakit AI. Kontak tidak langsung terjadi apabila ternak atau manusia sehat terpapar virus melalui droplet aerosol (hidung dan mata), feses, paparan muntahan ataupun virus yang terbang di udara.

c. Gejala Klinis Penyakit AI

Pada ternak unggas beberapa gejala klinis yang bisa dijadikan pedoman dalam mengenali ternak yang terjangkit penyakit AI antara lain sianosis atau warna biru pada jengger dan pial, munculnya ptechie (titik pendarahan) pada bagian kaki, munculnya 
warna merah pada sub-cutan kulit yang menandakan terjadinya pendarahan. Selanjutnya apabila dilakukan pembedahan akan ditemukan tanda merah bekas pendarahan pada organ proventrikulus, trachea, ovarium dan usus.

Tim pelaksana telah mengunjungi 3 lokasi sekolah selama bulan Mei hingga Agustus tahun 2014 guna melaksanakan kegiatan penyuluhan biosekuriti AI (Tabel 2). Kegiatan penyuluhan dilakukan secara serial pada sekolah-sekolah yang menjadi mitra kegiatan. Pada kegiatan penyuluhan 1 diikuti oleh sebanyak 46 orang siswa SMA N 3 Pondok Kelapa yang terdiri atas 29 perempuan dan 17 pria, dan sebanyak 10 orang siswa SMP Negeri 1 Pondok Kelapa: 10 orang yang terdiri dari 5 perempuan dan 5 pria.

Tabel 2. Kegiatan Penyuluhan dalam PPM IbM tahun 2014

\begin{tabular}{cccccc}
\hline No & Tanggal & Kegiatan & Lokasi & Peserta & Hasil \\
\hline 1 & $26 / 05 / 2014$ & Penyuluhan & SMA N 3 & Siswa \& dewan & Terlaksana \\
& & Biosekuriti & Pondok & guru SMA N 3 dan & dengan baik \\
& & AI & Kelapa & SMP N 1 & \\
2 & $08 / 08 / 2014$ & Penyuluhan & SMP N 2 & Siswa \& dewan & Terlaksana \\
& & Biosekuriti & Giri Mulya & guru SMP N 2 & dengan baik \\
& & AI & & & \\
3 & \multirow{2}{*}{$12 / 08 / 2014$} & Penyuluhan & SD N 7 & Siswa \& dewan & Terlaksana \\
& & Biosekuriti & Kerkap & guru SD N 7 & dengan baik \\
& & AI & & & \\
\hline
\end{tabular}

Pada kegiatan penyuluhan 2 (Tabel 2), diikuti oleh sebanyak 52 orang yang terdiri atas siswa kelas IX A, IX B dan IX C SMP Negeri 2 Giri Mulya. Sedangkan pada kegiatan penyuluhan ke 3 diikuti oleh 27 orang siswa kelas 6 dan dewan guru SD Negeri 7 Kerkap. Setelah presentasi, siswa peserta kegiatan penyuluhan diberikan kuisioner tentang gambaran pengetahuan, sikap dan perilaku siswa terhadap pencegahan penyakit AI yang terdiri atas bagian:

a. Identitas Responden

b. Pertanyaan Mengenai Pengetahuan

c. Pertanyaan Mengenai Sikap

Tahapan kegiatan berikutnya adalah tim pelaksana program PPM IbM tahun 2014 melakukan kegiatan pembentukan Pos Edukasi AI pada sekolah mitra yang telah dikunjungi pada kegiatan penyuluhan biosekuriti AI (Tabel 3). Bekerjasama dengan Kepala Sekolah serta dewan guru, tim pelaksana menghubungi beberapa siswa dari tiap sekolah yang bersedia untuk menjadi pengurus Pos Edukasi (Gambar 1). Tujuan dari pembentukan Pos Edukasi AI adalah sebagai media pendidikan bagi siswa-siswi sekolah mitra serta masyarakat yang berdomisili di sekitar lingkungan sekolah tersebut agar dapat lebih memahami tentang .penyakit AI, cara penularan AI dan gejala klinis AI sehingga 
akan meningkatkan pemahaman mereka tentang AI. Selanjutnya diharapkan siswa, guru dan masyarakat dapat menjadi orang-orang yang tanggap terhadap penyakit AI.

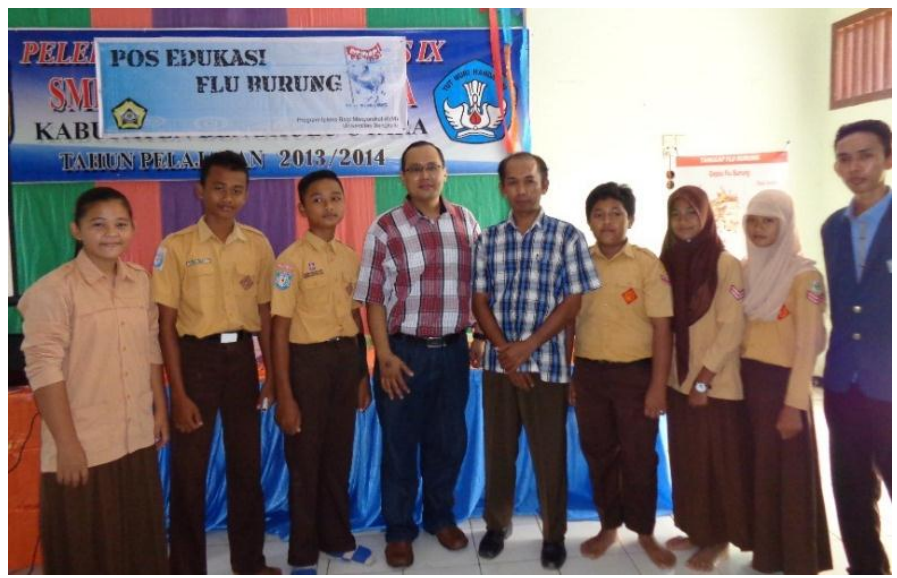

Gambar 1. Pengurus Pos Edukasi AI Pada Salah Satu Sekolah Mitra

Tabel 3. Pembentukan Pos Edukasi AI di Sekolah Mitra

\begin{tabular}{clll}
\hline No & Lokasi Pos Edukasi AI & \multicolumn{1}{c}{ Pengurus } & \multicolumn{1}{c}{ Dokumen } \\
\hline 1 & SMA N 3 & Ketua: Rahmat Bagus & Surat Keterangan tanggal \\
& Pondok Kelapa & Wakil : Puji Teri & 9 Mei 2014 (Dra. \\
& & Sekretaris : Fitra Nengsih & Susilowati) \\
& & Bendahara : Eko Armiyanti & \\
2 & SMP Negeri 2 & Ketua: Tidha & Surat Keterangan tanggal \\
& Giri Mulya & Wakil : Willey & 9 Agustus 2014 \\
& & Sekretaris : Ahmad Yusuf & (Katwanto, S.Pd) \\
& & Bendahara : Umi Sheila & \\
3 & SD Negeri 7 & Ketua: Riko Java & Surat Keterangan tanggal \\
& Kerkap & Wakil : M. Najib Ali & 19 Agustus 2014 \\
& & Sekretaris : Alga Dewi & (Junaedi, S.Pd) \\
& & Bendahara : Gusti Fadly & \\
\hline
\end{tabular}

Pada setiap Pos Edukasi AI, setiap pengurus dan anggota diberikan latihan tentang biosekuriti AI. Setiap Pos Edukasi juga diberikan pamflet tentang biosekuriti AI yang bebas untuk diakses oleh siswa dan masyarakat. Pos Edukasi AI juga dilengkapi dengan spanduk papan nama agar mudah dikenali oleh siswa-siswi sekolah mitra serta masyarakat sekitar sekolah mitra (Gambar 2). 


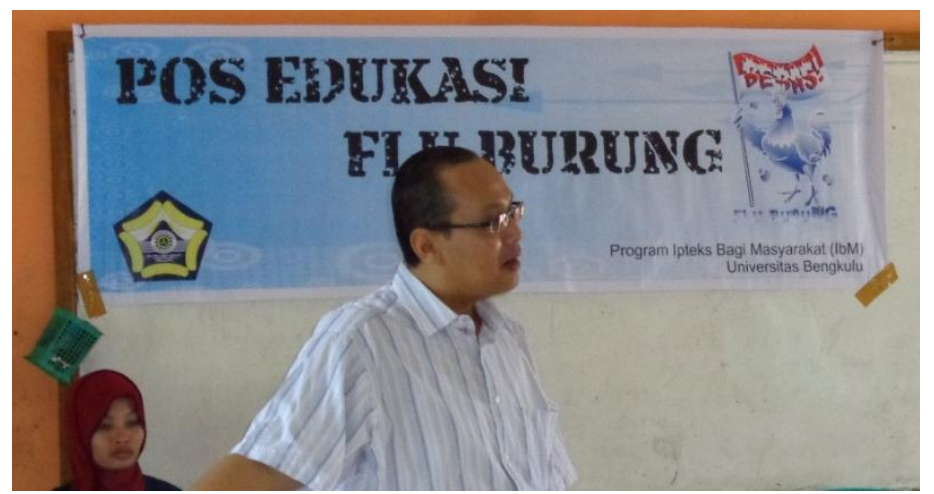

Gambar 2. Salah Satu Pos Edukasi Pada Salah Satu Sekolah Mitra

Pengetahuan merupakan domain yang sangat penting untuk terbentuknya perilaku dan tindakan seseorang oleh karena itu pengetahuan masyarakat dalam kaitannya dengan penyebaran penyakit AI sangat penting untuk melihat sejauh mana pengetahuan mereka tentang penyebab, cara penularan dan pencegahan penyakit AI agar terhindar kemungkinan terjangkit penyakit AI (Natsir, 2010:7). Ditambahkan oleh Yudhastuti dan Sudarmaji (2006: 184), virus AI (H5N1) dapat menyebar dengan cepat di antara populasi unggas dengan kematian yang tinggi. Bahkan dapat menyebar antarpeternakan dari suatu daerah ke daerah lain. Penyakit ini juga teridentifikasi bersifat zoonosis, yaitu menular dari hewan ternak ke manusia.

Selanjutnya Yudhastuti dan Sudarmaji (2006:185) menyebutkan bahwa Penularan Antar-Ternak Unggas (dari unggas ke unggas lain atau dari peternakan ke peternakan lainnya) dapat terjadi melalui:

a. Kontak langsung dari unggas terinfeksi dengan hewan yang peka.

b. Melalui lendir yang berasal dari hidung dan mata.

c. Melalui kotoran (feses) unggas yang terserang flu burung.

d. Lewat manusia melalui sepatu dan pakaian yang terkontaminasi dengan virus.

e. Melalui pakan, air, dan peralatan kandang yang terkontaminasi.

f. Melalui udara karena memiliki peran penting dalam penularan dalam satu kandang, tetapi

memiliki peran terbatas dalam penularan antarkandang.

g. Melalui unggas air yang dapat berperan sebagai sumber (reservoir) virus dari dalam saluran intestinal dan dilepaskan lewat kotoran.

Lebih jauh disebutkan bahwa Penularan dari Ternak ke Manusia dibatasi oleh jarak dan intensitas dalam aktivitas yang berinteraksi dengan kegiatan peternakan. Semakin dekat jarak peternakan yang terkena wabah virus dengan lingkungan manusia maka peluang untuk menularnya virus bisa semakin besar (Yudhastuti dan Sudarmaji, 2006:186). Penularan virus ke manusia lebih mudah terjadi jika orang tersebut melakukan kontak langsung dengan aktivitas ternak. Perlu diperhatikan pula cara pengolahan dan pemasakan daging unggas. Daging yang dimasak harus dipastikan benar -benar matang untuk menghindari adanya sisa kehidupan dari virus. Kematian virus dapat terjadi jika 
dipanaskan dengan suhu $60^{\circ} \mathrm{C}$ selama 3 jam. Semakin meningkat suhu akan semakin cepat mematikan virus.

Menurut Yudhastuti dan Sudarmaji (2006:188), Penularan Antar-Manusia pada kasus pandemi AI terjadi pada orang yang mempunyai risiko besar terserang AI seperti pekerja peternakan unggas, penjual, penjamah unggas, sampai ke dokter hewan yang bertugas memeriksa kesehatan ternak di peternakan. Sampai saat ini, peneliti meyakini bahwa AI ditularkan dari unggas ke manusia. Kemungkinan penularan AI antar-manusia kemungkinannya cukup kecil, tetapi tetap perla diwaspadai. Hal ini dikarenakan virus cepat bermutasi dan beradapasi dengan manusia sehingga memungkinkan adanya varian baru dari AI.

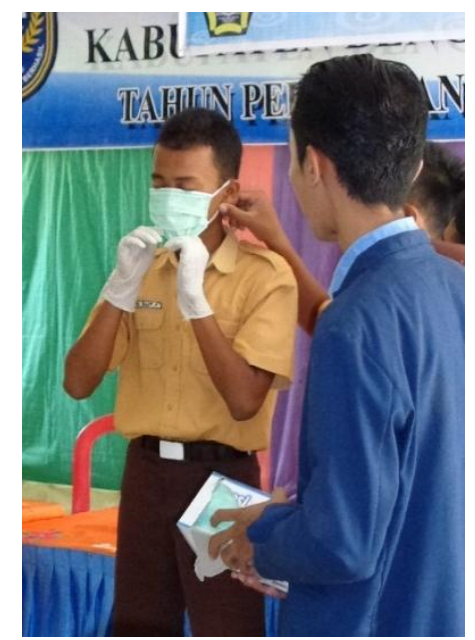

Gambar 3. Kegiatan Demplot Praktik Penyemprotan Desinfektan Biosekuriti AI

Pada kegiatan demplot praktik penyemprotan desinfektan pada tempat dan alat-alat kandang yang dicurigai terkontaminasi oleh virus AI, siswa-siswa diajak langsung untuk mempraktikkan beberapa hal penting yang berkaitan dengan biosekuriti AI (Gambar 3). Peralatan yang dipergunakan saat demplot praktik penyemprotan desinfektan antara lain 1 buah sprayer/penyemprot, 1 kaleng desinfektan liquid ukuran $200 \mathrm{ml}, 1$ pak masker, 1 kotak sarung tangan karet/glove dan 1 pasang sepatu karet.

Selama mengikuti kegiatan demplot praktik penyemprotan desinfektan, siswa-siswi sekolah mitra diberikan arahan tentang :

- Metode pencampuran air dengan cairan desinfektan sesuai dosis yang dianjurkan.

- Cara melindungi diri penyemprot dengan memakai sarung tangan, masker dan sepatu karet.

- Metode penyemprotan dengan mempertimbangkan waktu (jam), keadaan cuaca (arah angin dan sinar matahari) dan keselamatan (kehadiran orang lain disekitar lokasi).

- Cara melindungi diri penyemprot dengan memakai sarung tangan, masker dan sepatu karet.

- Strategi yang harus dilakukan saat di sekitar lokasi sekolah atau rumah tinggalnya ditemukan unggas yang terindikasi terjangkit penyakit flu burung. 
Tahapan-tahapan kegiatan PPM IbM tahun 2014 tentang pembentukan Pos Edukasi AI pada sekolah mitra telah sesuai dengan pendapat dan hasil kegiatan dari Yudhastuti dan Sudarmaji (2006:192) serta Natsir (2010:21). Kedua peneliti telah melakukan kegiatan berupa sosialisasi AI dalam bentuk penyuluhan ke peternakan di masing-masing daerahnya. Adanya penyuluhan diharapkan siswa dan warga di sekitar lokasi peternakan mengerti dan paham akan bahaya AI. Dengan demikian, siswa dan masyarakat akan menjaga kondisi lingkungan dan kesehatannya. Pengertian siswa dan masyarakat akan bahaya AI, diharapkan akan memotivasi siswa dan masyarakat di Provinsi Bengkulu cepat tanggap dalam mengambil langkah-langkah yang harus dilakukan dalam menghadapi kejadian munculnya penyakit AI.

\section{KESIMPULAN}

Tahapan kegiatan PPM IbM tahun 2014 telah berhasil dilaksanakan di 3 sekolah mitra yang ada di Provinsi Bengkulu. Target kegiatan berupa Pos Edukasi AI telah berhasil didirikan pada 3 sekolah mitra dan bersinergi dengan siswa-siswi yang menjadi pengurus pos edukasi.

\section{UCAPAN TERIMA KASIH}

Tim pelaksana PPM IbM tahun 2014 mengucapkan terima kasih kepada Direktorat Jenderal Pendidikan Tinggi Kementerian Pendidikan dan Kebudayaan Republik Indonesia yang telah mendanai kegiatan ini melalui dana pengabdian Ipteks Bagi Masyarakat (IbM) dengan nomor kontrak 5306/UN30.6.5/HK/2014 tanggal 7 Mei 2014. Ucapan terima kasih juga ditujukan kepada LPPM UNIB, mitra kegiatan yakni instansi DKPP Kabupaten Bengkulu Tengah serta sekolah mitra.

\section{DAFTAR PUSTAKA}

Darminto., 2006, Mengenal Flu Burung dan Strategi Pengendaliannya, An Introduction to Avian Influenza and it's Control Strategy.

Food and Agriculture Organization (FAO)., 2014, Pencegahan dan Pengendalian Flu Burung (Avian Influenza) pada Peternakan Unggas Skala Kecil Buku Petunjuk Bagi Paramedik Veteriner, Food and Agriculture Organization and Agronomes \& Vétérinaires Sans Frontières (VSF-CICDA).

Natsir, M., 2010, Faktor Risiko Kejadian Flu Burung Pada Peternakan Unggas Rakyat Komersial di Kabupaten Sidenreng Rappang 2007-2009, Jurnal Kesehatan Hewan.

Nurmeliasari, Putranto, H.D., Prakoso, H., 2014, IbM Pembentukan Pos Edukasi Flu Burung Untuk Menciptakan Masyarakat Yang Tanggap Flu Burung di Kabupaten 
Bengkulu Tengah dan Kabupaten Bengkulu Utara, Proposal IbM, Bengkulu: LPPM Universitas Bengkulu.

Putranto, H.D., Setianto, J., Santoso, U., Warnoto, Nurmeliasari, Zueni, A., 2012, Estradiol-17 $\beta$ hormone concentration and follicles number in exotic burgo chicken supplemented by extract of katuk leaves (Sauropus androgynus), Journal of Biological Diversity, 13 (1), 1-6.

Radji, M., 2006, Avian Influenza a (H5N1): Patogenesis, Pencegahan dan Penyebaran Pada Manusia, Majalah Ilmu Kefarmasian, III (2), 55-65.

Yudhastuti, R., dan Sudarmaji, 2006, Mengenal Flu Burung dan Bagaimana Kita Menyikapinya, Jurnal Kesehatan Lingkungan, 2 (2), 183 - 194. 